\title{
Anterior ischemic optic neuropathy due to biopsy-proven giant cell arteritis in Thai patients
}

\author{
This article was published in the following Dove Press journal: \\ Clinical Ophthalmology \\ 12 June 2015 \\ Number of times this article has been viewed
}

\author{
Taweevat Attaseth' \\ Kavin Vanikieti' \\ Anuchit Poonyathalang' \\ Pisit Preechawat ${ }^{1}$ \\ Panitha Jindahra ${ }^{2}$ \\ Duangkamon \\ Wattanatranon ${ }^{3}$ \\ 'Department of Ophthalmology, \\ ${ }^{2}$ Department of Medicine, \\ ${ }^{3}$ Department of Pathology, Faculty \\ of Medicine, Ramathibodi Hospital, \\ Mahidol University, Bangkok, Thailand
}

Correspondence: Taweevat Attaseth Department of Ophthalmology, Faculty of Medicine, Ramathibodi Hospital, Mahidol University, 270 Rama VI Road, Bangkok 10400, Thailand

Tel +668I4930193

Email taweevat_at@hotmail.com

\begin{abstract}
Giant cell arteritis is a systemic granulomatous vasculitis affecting medium to large arteries. An arteritic anterior ischemic optic neuropathy is the most common cause of permanent visual loss. Giant cell arteritis is very rare among Asians. We report six patients with biopsyproven arteritic anterior ischemic optic neuropathy. Demographic data, clinical manifestations, laboratory findings, treatment, and visual outcome are described in detail and compared with Caucasian patients. We found no differences in any clinical features except for sex preference. Moreover, perioptic nerve sheath enhancement was observed in half of our patients.
\end{abstract}

Keywords: giant cell arteritis, temporal artery biopsy, perioptic nerve sheath enhancement, choroidal ischemia, Asian

\section{Introduction}

Giant cell arteritis (GCA) is a vasculitis of medium to large sized arteries, it can interfere with arterial flow to the optic nerve head causing arteritic anterior ischemic optic neuropathy (A-AION). It is the most common form of systemic vasculitis affecting elderly persons, which commonly occurs in the Caucasian population. ${ }^{1}$ Overall annual incidence of GCA is 15-25 per 100,000 in American and North European people over the age of 50 years and significantly higher in women. ${ }^{2}$ The disease seems to be infrequent in Asians, but the data are sparse. In a study from Japan, the prevalence is extremely low at 1.47 per 100,000 population. ${ }^{3}$ The incidence of GCA is unknown in Thailand and only a few case reports have been published. ${ }^{4}$ Although GCA is a well-known cause of A-AION, there is not sufficient information about Thai patients probably due to its rarity.

\section{Patients and methods}

Medical records of all patients with anterior ischemic optic neuropathy (AION) seen in Neuro-Ophthalmology Unit at Department of Ophthalmology, Ramathibodi Hospital from January 2005 through October 2014 were reviewed. Only patients with AION and biopsy-proven GCA were included in this study. The diagnosis of GCA requires three or more of the following criteria: ${ }^{5} 1$ ) age of onset greater than 50 years; 2) new onset headache; 3 ) temporal artery abnormality on examination (tender or reduced pulsation); 4) elevated erythrocyte sedimentation rate (ESR) $>50 \mathrm{~mm} / \mathrm{hr}$; 5) abnormal temporal arterial biopsy, showing necrotizing vasculitis with predominant mononuclear cell infiltration or granulomatous inflammation. Patients were evaluated in a standard fashion and underwent a systematic comprehensive neuro-ophthalmic history and examination, including dilating funduscopic examination, formal visual field testing by Goldmann perimetry or Humphrey Automated Field Analyzer 30-2, fundus fluorescein angiography, and indocyanine green angiography. Each patient underwent a thorough work-up evaluating for other causes of optic neuropathy and other systemic 

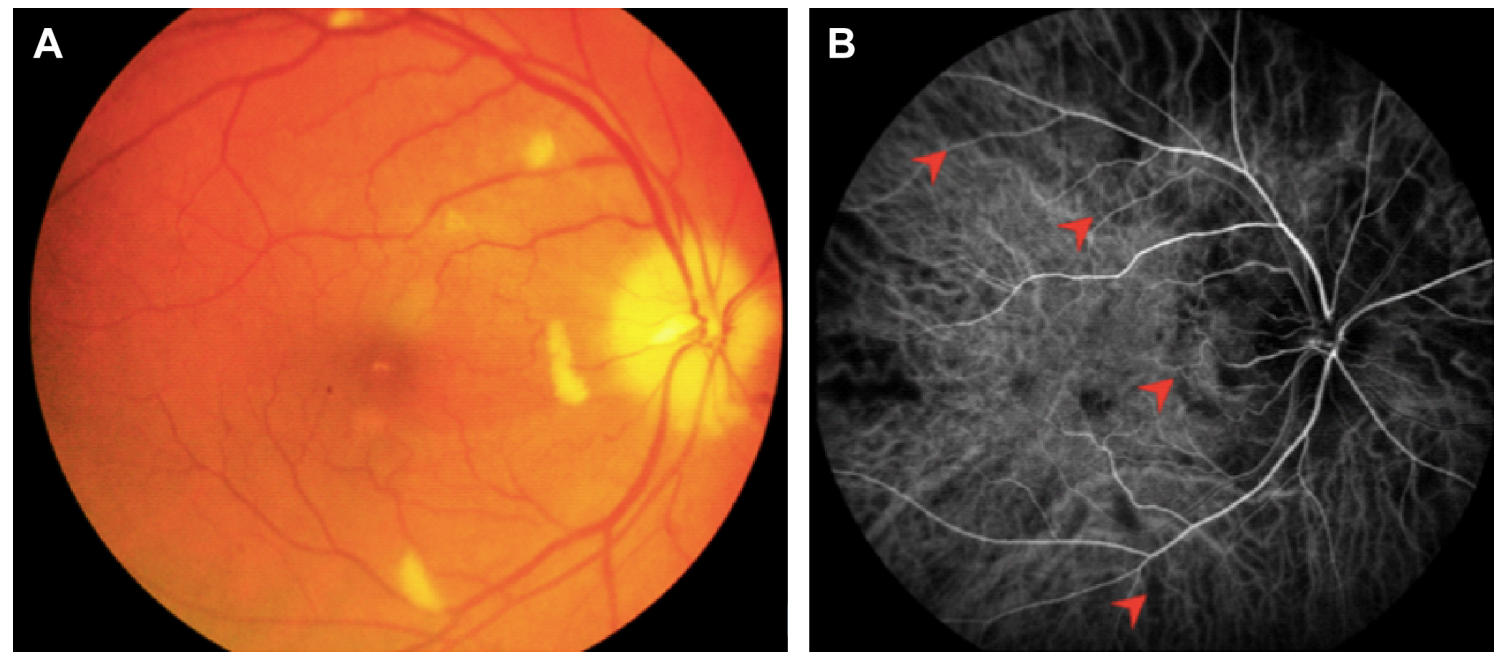

Figure I (A) Fundus photograph at presentation of patient 2 shows "chalky white" pallid disc edema with multiple cotton wool spots away from optic disc. (B) Indocyanine green angiography at 25 seconds shows multiple areas of choroidal non-perfusion (arrow heads).

vasculitis, including blood tests, cerebrospinal fluid analysis and magnetic resonance imaging (MRI) of brain and orbit. ESR and CRP were tested in all cases.

\section{Results \\ Demographic data}

During the period 2005-2014, there were 236 patients diagnosed with AION. Temporal artery biopsies were performed in 20 patients with clinical suspicion of GCA and positive biopsy results were found in only six patients (2.5\%). Summarized information of all patients are shown in Table 1. Four patients (67\%) were male. Mean age at onset was 72.5 years, ranging from 63 to 81 years.

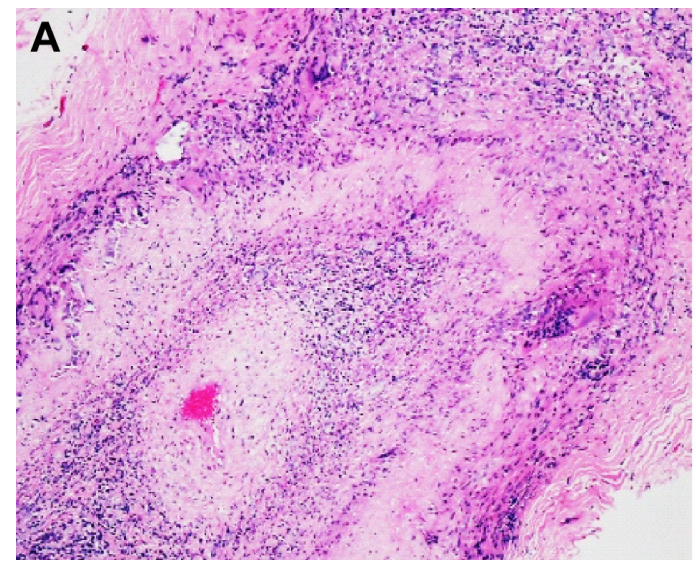

\section{Clinical presentation}

Of the six patients with biopsy-proven GCA, two had bilateral, simultaneous onset of A-AION and four had unilateral involvement (eight eyes in total). In the unilateral A-AION group, two patients developed contralateral visual loss from cilioretinal artery occlusion 2 weeks before the onset of A-AION. All eyes had severe visual loss (20/200 or worse) at initial presentation. No light perception was detected in three eyes. The mean duration of visual loss was 8.2 days, ranging from 1 day to 17 days. Optic discs appeared diffusely swollen and pale in all patients (Figure 1). Neither peri-papillary hemorrhages nor exudates were found. Retinal cotton wool spots were identified in three eyes (two patients). One patient experienced

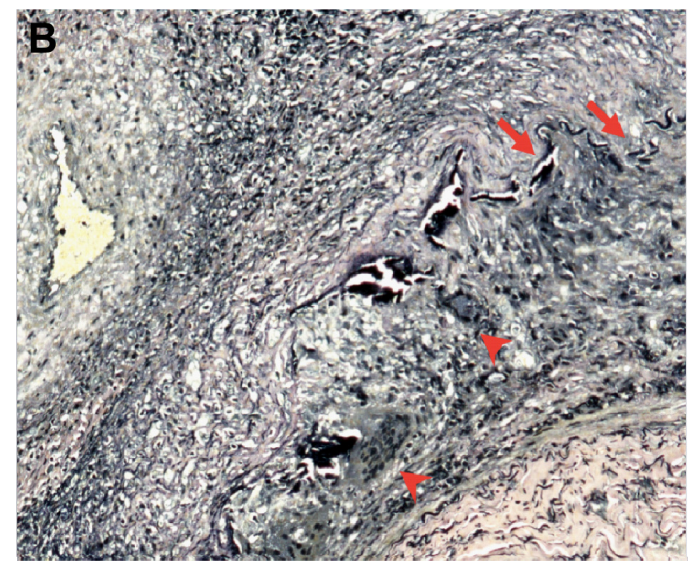

Figure 2 (A) Microscopic finding of temporal artery of patient 2 reveals luminal occlusion owing to intimal myofibroblastic proliferation. The inflammation is also present in the intimal and medial layers (hematoxylin and eosin stain $\times 40$ ). (B) Elastic lamina fragmentation (arrows) and multinucleated giant cells (arrow heads) in the media, which is an area of elastic destruction (elastic stain $\times 200$ ). 
Table I Demographics, visual presentation and outcome, and MRI findings

\begin{tabular}{|c|c|c|c|c|c|c|}
\hline $\begin{array}{l}\text { Patient } \\
\text { number }\end{array}$ & $\begin{array}{l}\text { Sex/age } \\
\text { (years) }\end{array}$ & Laterality & $\begin{array}{l}\text { Duration of } \\
\text { visual loss (days) }\end{array}$ & Presenting VA & Final VA & $\begin{array}{l}\text { Orbital MRI } \\
\text { findings }\end{array}$ \\
\hline \multirow[t]{2}{*}{ I } & $M / 78$ & Bilateral & 3 & LP & $20 / 50$ & ON sheath \\
\hline & & & & HM & HM & enhancement \\
\hline 2 & $M / 70$ & Unilateral & 3 & HM & $20 / 50$ & Normal study \\
\hline \multirow[t]{2}{*}{3} & $M / 75$ & Bilateral & 9 & NLP & NLP & ON sheath \\
\hline & & & & NLP & NLP & enhancement \\
\hline 4 & $\mathrm{~F} / 63$ & Unilateral & 16 & $\mathrm{CF}$ & $\mathrm{CF}$ & $\begin{array}{l}\text { ON sheath } \\
\text { enhancement }\end{array}$ \\
\hline 5 & $M / 68$ & Unilateral & I & NLP & NLP & Normal study \\
\hline 6 & $\mathrm{~F} / 8 \mathrm{I}$ & Unilateral & 17 & $20 / 200$ & $20 / 100$ & Not done \\
\hline
\end{tabular}

Abbreviations: LP, light perception; NLP, no light perception; HM, hand motion; CF, counting fingers; ON, optic nerve; MRI, magnetic resonance imaging; M, male; F, female; VA, visual acuity.

ipsilateral transient monocular visual loss prior to the onset of A-AION. Systemic symptoms were present before and at the time of visual loss in three patients $(50 \%)$. These included headache and at least one of the following symptoms: scalp tenderness, jaw claudication, fever and general malaise, and anorexia and weight loss. Abnormal superficial temporal arteries were found during examination in three cases. No patients complained of diplopia. Fundus fluorescein angiography and indocyanine green angiography were performed in four patients. Delayed choroidal filling time was demonstrated in all, whereas, choroidal non-perfusion was found in one patient (Figure 2). MRIs of orbit and brain were performed in five patients. Abnormal MRI findings were shown in three patients (Figure 3). Perineural enhancement of the intraorbital part of the optic nerves was observed in these three patients. Their optic nerve signals were normal. Stranding of bilateral intraorbital fat was also identified. Diffuse weighted image sequences performed in two patients with abnormal MRI findings were unremarkable. There were no imaging signs of cerebral vasculitis in any of the patients. The mean ESR was
$95 \mathrm{~mm} / \mathrm{hr}(75-102 \mathrm{~mm} / \mathrm{hr})$. CRP was high in four patients, $(17-122 \mathrm{mg} / \mathrm{L})$. There were four patients with anemia and two patients with thrombocytosis.

\section{Treatment and visual outcome}

High dose of intravenous methylprednisolone ( $1 \mathrm{~g}$ per day for 3 days) and subsequent long-term oral corticosteroid were given in all cases. Oral steroid was slowly tapered on the basis of symptoms, ESR, and CRP. Follow-up period ranged from 5 months to 120 months. The disc edema in all eyes resolved within 6 weeks after treatment. Final visual acuity remained unchanged in most of the patients (five eyes, 63\%). Three eyes (37\%) showed visual acuity improvement and two eyes achieved a final visual acuity of 20/50. All patients eventually developed diffuse optic atrophy in the affected eyes.

\section{Discussion}

This study showed that the clinical manifestations of GCA in Thai patients were similar to those previously described except for the sex preference (Table 2). ${ }^{1,2,6,7}$ All patients aged over

Table 2 Comparison of characteristics of A-AION due to biopsy-proven GCA between our study and a United States study

\begin{tabular}{|c|c|c|}
\hline Characteristic & Our study $(n=6)$ & Liu et $\mathrm{al}^{6}(\mathrm{n}=45)$ \\
\hline Region & Thailand & United States \\
\hline Mean age (years) & 72.5 & 71.1 \\
\hline Sex & $33 \%$ female & $69 \%$ female \\
\hline \multirow[t]{3}{*}{ Associated symptoms } & Headache $100 \%$ & Headache $58 \%$ \\
\hline & Jaw claudication $16 \%$ & Jaw claudication $53 \%$ \\
\hline & Weight loss $16 \%$ & Weight loss $31 \%$ \\
\hline Visual acuity & Light perception or worse in $50 \%$ & $20 / 200$ or worse in $70 \%$, no light perception in $21 \%$ \\
\hline Disc & Pallid swelling and normal cupping in all cases & Pallid swelling, normal cupping \\
\hline ESR & Mean $95 \mathrm{~mm} / \mathrm{hr}$ & Mean 83 mm/hr \\
\hline FA/ICG & Delayed choroidal filling time, choroidal non-perfusion & $\mathrm{N} / \mathrm{A}$ \\
\hline Natural history & $37 \%$ visual improvement & $34 \%$ visual improvement \\
\hline
\end{tabular}

Abbreviations: A-AION, arteritic anterior ischemic optic neuropathy; GCA, giant cell arteritis; ESR, erythrocyte sedimentation rate; hr, hour; FA, fundus fluorescein angiography; ICG, indocyanine green angiography; N/A, not applicable. 

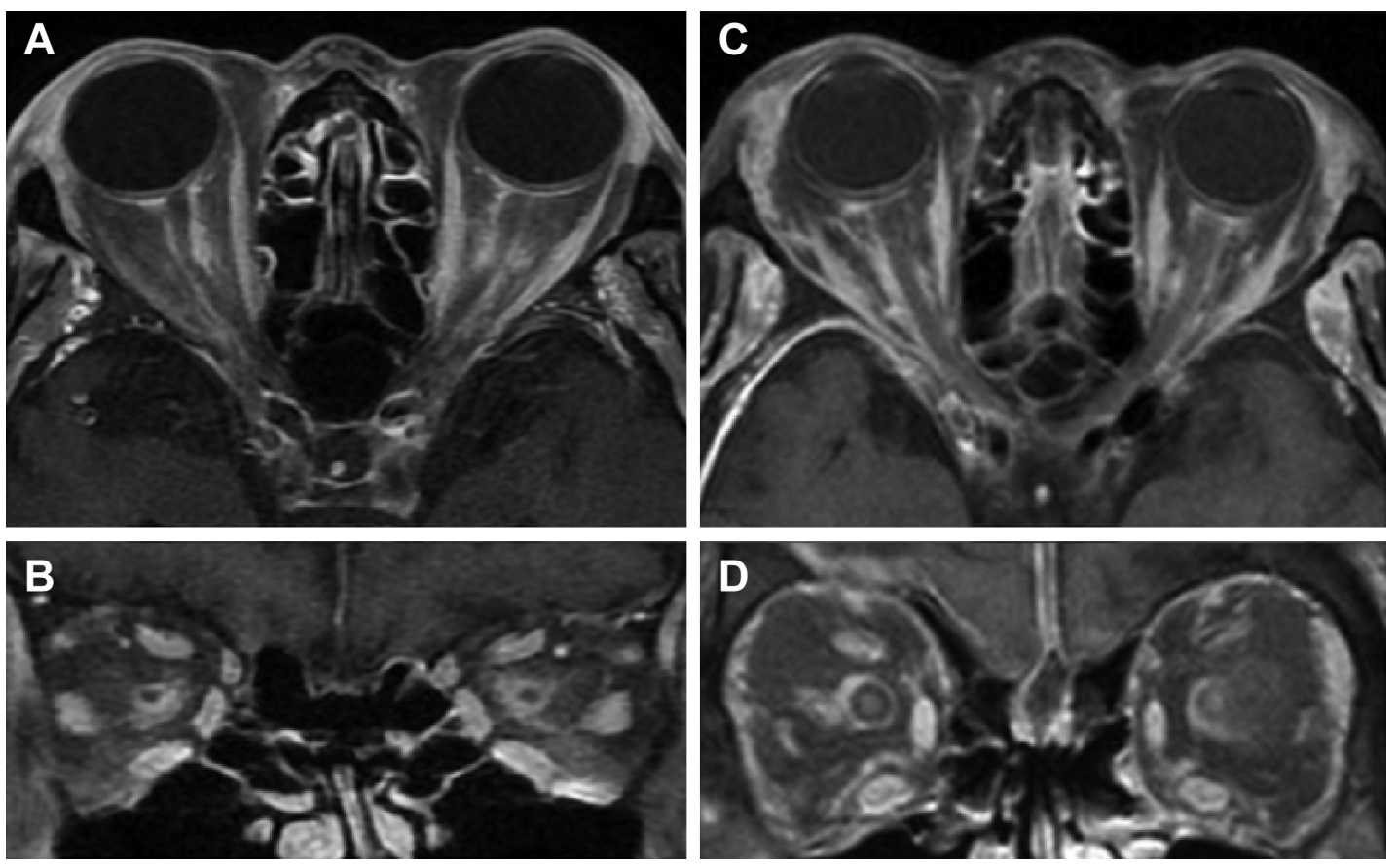

Figure 3 Post contrast axial and coronal TI-weighted magnetic resonance imaging with fat suppression shows perineural enhancement of both optic nerves and orbital fat enhancement in patient I (A, B) and patient 3 (C, D).

60 years, presented with a rapid onset of severe visual loss and developed typical pallid "chalky white" disc edema. They all had a significantly elevated ESR and most of them had high CRP levels. Systemic symptoms, anemia, and/or thrombocytosis were found in approximately half of the patients. Although the visual prognosis is very poor in A-AION, a study revealed some recovery of vision in one third of cases. ${ }^{1}$ The result of our study confirms the potential of visual recovery after corticosteroid treatment. In the past, orbital MRI was not done in typical GCA cases as it is mainly diagnosed on clinical grounds. However, there is increasing evidence of abnormal enhancement of the optic nerve in GCA using T1-weighted images with gadolinium. ${ }^{8-10}$ The optic nerve sheath involvement is prominent in those cases. Biopsy of the optic nerve sheath showed inflammation of the perineural vasculature with multinucleated giant cells and disruption of the internal elastic lamina. ${ }^{9}$ Likewise, we showed perineural enhancement of the optic nerve in three out of six patients. The mechanism of selective enhancement of optic nerve sheath is still not known but the theory of blood optic nerve barrier disruption has been proposed. ${ }^{10}$

\section{Conclusion}

Arteritic AION caused by GCA is not common in Thailand. The clinical features and visual outcome in Thai patients are not different from those described in Asian and Caucasian populations. Enhancement of the perioptic nerve sheath can be detected in A-AION. It might be useful in GCA diagnosis particularly in difficult cases. Further studies are required to evaluate its clinical application.

\section{Acknowledgment}

This paper was presented at the North American NeuroOphthalmology Society 41st Annual Meeting as a poster presentation with interim findings. The poster's abstract was published in "Poster Abstracts" in program information of the meeting: http://www.nanosweb.org/files/2015\%20 Poster $\% 20$ Table $\% 20$ of $\% 20$ ContentsFULLI.pdf.

\section{Disclosure}

The authors report no conflicts of interest in this work.

\section{References}

1. Rahman W, Rahman FZ. Giant cell (temporal) arteritis: an overview and update. Surv Ophthalmol. 2005;50(5):415-428.

2. Kale N, Eggenberger E. Diagnosis and management of giant cell arteritis: a review. Curr Opin Ophthalmol. 2010;21(6):417-422.

3. Kobayashi S, Yano T, Matsumoto Y, et al. Clinical and epidemiologic analysis of giant cell (temporal) arteritis from a nationwide survey in 1998 in Japan: the first government-supported nationwide survey. Arthritis Rheum. 2003;49(4):594-598.

4. Aui-Aree N, Tungsinmunkong K, Hirunpat S, Ratanasukon M, Wangsupadilok B. A variety of atypical manifestations in giant cell arteritis. J Med Assoc Thai. 2010;93(5):629-632.

5. Hunder GG, Bloch DA, Michel BA, et al. The American College of Rheumatology 1990 criteria for the classification of giant cell arteritis. Arthritis Rheum. 1990;33(8):1122-1128. 
6. Liu GT, Glaser JS, Schatz NJ, Smith JL. Visual morbidity in giant cell arteritis. Ophthalmology. 1994;101(11):1779-1785.

7. Cheng CK, Lee CC, Huang KH, Wu TE, Peng PH. Giant cell (Temporal) arteritis with anterior ischemic optic neuropathy: a biopsy-proven case in Taiwan. J Formos Med Assoc. 2010;109(7):550-554.

8. Lee AG, Eggenberger ER, Kaufman DI, Manrique C. Optic nerve enhancement on magnetic resonance imaging in arteritic ischemic optic neuropathy. J Neuroophthalmol. 1999;19(4):235-237.
9. Morgenstern KE, Ellis BD, Schochet SS, Linberg JV. Bilateral optic nerve sheath enhancement from giant cell arteritis. $J$ Rheumatol. 2003;30(3):625-627.

10. Liu KC, Chesnutt DA. Perineural optic nerve enhancement on magnetic resonance imaging in giant cell arteritis. $J$ Neuroophthalmol. 2013;33(3):279-281.
Clinical Ophthalmology

\section{Publish your work in this journal}

Clinical Ophthalmology is an international, peer-reviewed journal covering all subspecialties within ophthalmology. Key topics include: Optometry; Visual science; Pharmacology and drug therapy in eye diseases; Basic Sciences; Primary and Secondary eye care; Patien Safety and Quality of Care Improvements. This journal is indexed on

Submit your manuscript here: http://www.dovepress.com/clinical-ophthalmology-journal

\section{Dovepress}

PubMed Central and CAS, and is the official journal of The Society of Clinical Ophthalmology (SCO). The manuscript management system is completely online and includes a very quick and fair peer-review system, which is all easy to use. Visit http://www.dovepress.com/ testimonials.php to read real quotes from published authors. 